\title{
Effects of chromium propionate supplementation during the periparturient period and early lactation on metabolism, performance, and cytological endometritis in dairy cows
}

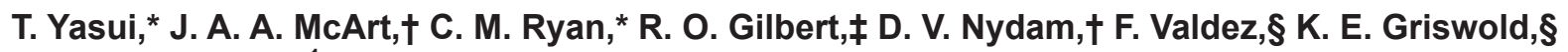 \\ and T. R. Overton*1 \\ *Department of Animal Science, Cornell University, Ithaca, NY 14853 \\ †Department of Population Medicine and Diagnostic Sciences, College of Veterinary Medicine, Cornell University, Ithaca, NY 14853 \\ $\ddagger$ Department of Clinical Sciences, College of Veterinary Medicine, Cornell University, Ithaca, NY 14853 \\ §Kemin Industries, Des Moines, IA 50317
}

\begin{abstract}
Multiparous Holstein cows $(\mathrm{n}=61)$ were used to determine the effects of chromium propionate (Cr-Pro) supplementation during the periparturient period and early lactation on metabolism, performance, and the incidence of cytological endometritis (CE). After a 1-wk preliminary period, cows were assigned randomly to 1 of 2 treatments from $21 \mathrm{~d}$ before expected calving through $63 \mathrm{~d}$ postpartum: (1) control $(\mathrm{n}=31)$ and (2) Cr-Pro $(\mathrm{n}=30)$ administered by daily topdress at a rate of $8 \mathrm{mg} / \mathrm{d}$ of $\mathrm{Cr}$. A tendency was detected for increased dry matter intake (DMI) during the prepartum period for cows fed Cr-Pro. Moreover, cows fed Cr-Pro tended to have lower plasma concentrations of nonesterified fatty acids during the prepartum period. However, effects of Cr-Pro supplementation on postpartum DMI and milk yield were not significant. Cows fed Cr-Pro tended to have higher urea N concentrations in milk. An interaction of treatment and day existed during the postpartum period, such that cows fed CrPro had lower plasma glucose concentrations within the first day postpartum compared with controls. Plasma haptoglobin concentration was not affected by treatment during the postpartum period. Blood neutrophil glycogen concentrations were not affected by treatment when sampled at either $7 \mathrm{~d}$ postpartum or on one day between 40 and $60 \mathrm{~d}$ ( $48 \mathrm{~d} \pm 0.44$ standard error) postpartum. Evaluation of endometrial cytology by low volume lavage at $7 \mathrm{~d}$ postpartum (first lavage) and on one day between 40 and $60 \mathrm{~d}$ (second lavage) postpartum revealed that cows fed Cr-Pro tended to have a higher percentage of neutrophils at first lavage and decreased
\end{abstract}

Received December 3, 2013.

Accepted June 22, 2014.

${ }^{1}$ Corresponding author: tro2@cornell.edu incidence of $\mathrm{CE}$ as assessed at second lavage. In conclusion, supplementation with Cr-Pro resulted in trends for increased DMI and lower plasma nonesterified fatty acids prepartum. Postpartum production and energy metabolism were not affected by treatment; however, Cr-Pro supplementation tended to affect the postpartum influx of neutrophils into the uterus and decreased the incidence of $\mathrm{CE}$, suggesting positive effects of $\mathrm{Cr}$ Pro supplementation on uterine health.

Key words: chromium, transition cow, cytological endometritis

\section{INTRODUCTION}

Chromium is essential to normal carbohydrate, lipid, and protein metabolism (Vincent, 2004; Pechova and Pavlata, 2007) and has been demonstrated to affect energy metabolism through modulating tissue responses to insulin (Vincent, 2004). The demand for $\mathrm{Cr}$ is typically increased during different forms of nutritional, metabolic, and physical stress (Pechova and Pavlata, 2007). Several studies conducted during the transition period and early lactation have demonstrated that cows fed supplemental $\mathrm{Cr}$ have increased milk yield (Hayirli et al., 2001; Smith et al., 2005; Sadri et al., 2009) and improved energy metabolism, as measured by lower circulating concentrations of NEFA or BHBA (Smith et al., 2008; Soltan, 2010; Sadri et al., 2012).

In addition to its effects on nutritional metabolism, several studies suggest that Cr may also have immunomodulatory effects in cattle. Chromium supplementation has affected cell-mediated immunity such that mitogen-stimulated blastogenic responses in peripheral blood mononuclear cells were elevated in cows fed $\mathrm{Cr}$ (Burton et al., 1993). Cows fed Cr had higher humoral immune responses such as increased anti-ovalbumin antibody (Burton et al., 1993) and tetanus toxoid-specific antibody (Faldyna et al., 2003) responses compared with control cows. Positive effects of $\mathrm{Cr}$ on innate im- 
munity have not been demonstrated to date (Chang et al., 1996; Spears, 2000); however, the possibility still exists that $\mathrm{Cr}$ affects innate immune responses because the level of serum cortisol was significantly decreased in stressed calves fed Cr (Mowat et al., 1993), and neutrophil function is known to be negatively affected by glucocorticoids in cattle (Burton et al., 1996).

Recent work has established linkages between energy metabolism during the periparturient period and reproductive performance (Butler et al., 2006; Roche et al., 2009; Ospina et al., 2010). Elevated concentrations of NEFA and BHBA in blood during the transition period were associated with decreased reproductive performance in a large field study (Ospina et al., 2010). One could speculate that these associations can be explained partly by the potential development of cytological endometritis (CE) because the odds of having CE were 3.9 times higher in cows with ketosis (Cheong et al., 2011). Further, the development of $\mathrm{CE}$ has been shown to negatively affect reproductive outcomes: lower first-service conception rate and longer days to pregnancy in a study conducted in 5 commercial dairy farms (Gilbert et al., 2005), and lower odds for pregnancy at first insemination and longer median days open in another study conducted in 779 cows from 38 herds (Cheong et al., 2011) in cows with CE compared with cows without CE. Uterine defenses are known to initially rely on innate immunity rather than adaptive immunity (Wathes et al., 2009). Therefore, it is possible that $\mathrm{Cr}$ supplementation affects the incidence of $\mathrm{CE}$ through its effects on either energy metabolism or immune function.

Given the potential effects of $\mathrm{Cr}$ supplementation on both energy metabolism and immune function, we hypothesized that $\mathrm{Cr}$ supplementation during the periparturient period and early lactation would improve aspects of metabolism and performance and decrease the incidence of cytological endometritis in cows. Therefore, the objective of this experiment was to evaluate the effect of $\mathrm{Cr}$ supplementation to cows during the periparturient period and early lactation on performance, metabolism, inflammatory response, and the incidence of $\mathrm{CE}$ in dairy cows.

\section{MATERIALS AND METHODS}

\section{Experimental Animals, Treatments, and Procedures}

All procedures involving animals were approved by the Cornell University Institutional Animal Care and Use Committee (Ithaca, NY) before the onset of the experiment. Holstein cows $(\mathrm{n}=61)$ entering second lactation or greater from the Cornell University Teach- ing and Research Center Dairy were enrolled in this experiment at $28 \mathrm{~d}$ before expected calving to allow for covariate data collection between d 28 and 21 before expected calving and then assigned at $21 \mathrm{~d}$ before expected calving to 1 of 2 topdress treatments with randomization restricted by $305-\mathrm{d}$ mature-equivalent milk production in the previous lactation. Treatments were administered from $21 \mathrm{~d}$ before expected calving through $63 \mathrm{~d}$ postcalving: (1) control (no topdress) and (2) chromium propionate (Cr-Pro; KemTRACE chromium propionate; Kemin Industries Inc., Des Moines, IA) administered by daily topdress at a rate of $8 \mathrm{mg}$ of $\mathrm{Cr} / \mathrm{d}$ immediately after feeding. All cows were housed in individual tie-stalls and fed the same basal diet during the prepartum period and also fed the same basal diet during the postpartum period.

Ingredient and chemical composition of the diets fed during the experiment are described in Table 1. Both prepartum and postpartum diets were typical of those fed in the northeastern United States. All nonforage ingredients were blended by a commercial feed mill into separate concentrate mixtures, and diet mixing at the farm consisted of mixing the component forages with the appropriate concentrate mixture. Fresh feed was provided each morning at $0800 \mathrm{~h}$, orts were weighed and recorded daily, and water was made available at all times by individual water cups. Samples of the forages and concentrate mixtures were obtained weekly throughout the experiment, and DM content was determined by drying at $55^{\circ} \mathrm{C}$ until static weight was obtained. Amounts of individual feed components in the TMR were adjusted weekly based on changes in the DM content of these feed components. The DM content of each TMR was used in calculating the DMI for the corresponding week. The weekly samples of forages, concentrate mixtures, and TMR were composited into 4-wk composite samples and submitted to a commercial laboratory to analyze for Cornell Net Carbohydrate and Protein System/Cornell-Penn-Miner profiles (Cumberland Valley Analytical Services, Hagerstown, MD). Samples were analyzed for DM (AOAC International, 2000; method 930.15), CP (AOAC International, 2000; method 990.03), soluble protein (Krishnamoorthy et al., 1982), ADF (AOAC International, 2000; method 973.18), NDF (Van Soest et al., 1991), starch (Hall, 2009), sugar (DuBois et al., 1956), ether extract (AOAC International, 2006; method 2003.05), ash (AOAC International, 2000; method 942.05), and minerals (AOAC International, 2000; method 985.01).

Cows were milked twice per day (0900 and $2100 \mathrm{~h}$ ) and milk yields were recorded at all milkings for the 63-d postpartum treatment period. Milk samples were collected on the same day each week from all milk- 
Table 1. Feed intake and chemical composition (DM basis, \% of DM unless otherwise noted) of experimental diets

\begin{tabular}{|c|c|c|}
\hline Item & Prepartum diet & Postpartum diet \\
\hline Corn silage (processed) & 42.83 & 51.29 \\
\hline Wheat straw & 27.59 & 2.04 \\
\hline Legume silage & - & 14.37 \\
\hline Shelled corn, finely ground & - & 2.65 \\
\hline Soybean meal $(47.5 \% \mathrm{CP})$ & - & 4.08 \\
\hline Wheat middlings & - & 4.04 \\
\hline Corn germ meal & 8.01 & 2.76 \\
\hline Distillers grains (with solubles) & 1.23 & 5.39 \\
\hline Soy Chlor ${ }^{1}$ & 2.67 & - \\
\hline Amino Plus ${ }^{2}$ & 5.39 & - \\
\hline Soybean hulls & 3.54 & 4.45 \\
\hline Canola meal & 5.86 & 1.78 \\
\hline Blood meal & - & 1.55 \\
\hline Dextrose & - & 1.14 \\
\hline Bypass fat ${ }^{3}$ & - & 1.25 \\
\hline Urea & - & 0.33 \\
\hline Calcium carbonate & 1.07 & 0.75 \\
\hline Calcium sulfate & 0.70 & 0.14 \\
\hline Sodium bicarbonate & - & 0.82 \\
\hline Monodicalcium phosphate & 0.23 & 0.08 \\
\hline Salt & 0.16 & 0.41 \\
\hline Magnesium oxide & 0.23 & 0.15 \\
\hline Copper sulfate & $<0.01$ & - \\
\hline Selenium $(0.06 \%)$ & 0.04 & 0.05 \\
\hline Trace mineral premix ${ }^{4}$ & 0.01 & 0.02 \\
\hline Vitamin A, D, E premix ${ }^{5}$ & 0.03 & 0.02 \\
\hline Vitamin E premix ${ }^{6}$ & 0.01 & - \\
\hline Condition $\mathrm{Aid}^{7}$ & 0.38 & 0.46 \\
\hline \multicolumn{3}{|l|}{ Chemical composition $\left( \pm \mathrm{SD}^{8}\right)$} \\
\hline $\mathrm{CP}$ & $13.6(0.59)$ & $16.9(0.34)$ \\
\hline Soluble protein, $\%$ of $\mathrm{CP}$ & $32.2(3.76)$ & $37.7(2.71)$ \\
\hline $\mathrm{ADF}$ & $28.4(0.62)$ & $21.9(0.71)$ \\
\hline $\mathrm{NDF}$ & $47.7(0.94)$ & $37.2(0.88)$ \\
\hline Starch & $19.9(1.67)$ & $25.3(1.27)$ \\
\hline Sugar & $3.18(0.46)$ & $3.00(0.30)$ \\
\hline Ether extract & $2.89(0.08)$ & $4.20(0.34)$ \\
\hline Ash & $6.92(0.35)$ & $6.70(0.33)$ \\
\hline $\mathrm{Ca}$ & $1.03(0.11)$ & $0.89(0.10)$ \\
\hline $\mathrm{P}$ & $0.39(0.01)$ & $0.40(0.01)$ \\
\hline $\mathrm{K}$ & $1.04(0.06)$ & $1.27(0.07)$ \\
\hline $\mathrm{Mg}$ & $0.37(0.02)$ & $0.34(0.02)$ \\
\hline $\mathrm{Na}$ & $0.14(0.01)$ & $0.45(0.06)$ \\
\hline $\mathrm{Cl}$ & $0.45(0.04)$ & $0.37(0.08)$ \\
\hline $\mathrm{S}$ & $0.30(0.04)$ & $0.26(0.03)$ \\
\hline $\mathrm{Fe}, \mathrm{mg} / \mathrm{kg}$ & $468.5(63.9)$ & $407.6(29.0)$ \\
\hline $\mathrm{Zn}, \mathrm{mg} / \mathrm{kg}$ & $63.2(7.25)$ & $73.7(7.70)$ \\
\hline $\mathrm{Cu}, \mathrm{mg} / \mathrm{kg}$ & $17.3(2.34)$ & $16.0(2.00)$ \\
\hline $\mathrm{Mn}, \mathrm{mg} / \mathrm{kg}$ & $62.8(5.56)$ & $64.1(5.64)$ \\
\hline $\mathrm{DCAD}^{9} \mathrm{mEq} / 100 \mathrm{~g}$ of $\mathrm{DM}$ & $1.50(3.73)$ & $25.6(3.15)$ \\
\hline
\end{tabular}

${ }^{1}$ Anionic feed supplement (West Central Coop., Ralston, IA).

${ }^{2}$ Rumen-undegradable protein supplement (AGP Inc., Omaha, NE).

${ }^{3}$ Prilled SFA (Cargill Inc., Minnetonka, MN).

${ }^{4}$ Contained $30,317 \mathrm{mg}$ of $\mathrm{Cu} / \mathrm{kg}, 136,466 \mathrm{mg}$ of $\mathrm{Mn} / \mathrm{kg}, 3,393 \mathrm{mg}$ of $\mathrm{Co} / \mathrm{kg}, 3,040 \mathrm{mg}$ of $\mathrm{I} / \mathrm{kg}$, and $153,916 \mathrm{mg}$ of $\mathrm{Zn} / \mathrm{kg}$.

${ }^{5}$ Contained 30,464 IU of vitamin A $/ \mathrm{kg}, 5,862 \mathrm{KIU}$ of vitamin $\mathrm{D} / \mathrm{kg}$, and $93,784 \mathrm{IU}$ of vitamin $\mathrm{E} / \mathrm{kg}$.

${ }^{6}$ Contained 499,400 IU of vitamin E/kg.

${ }^{7}$ Flow agent (Oil-Dri Corporation of America, Chicago, IL).

${ }^{8}$ Standard deviation calculated from 6 and 7 samples for prepartum and postpartum diet, respectively.

${ }^{9}$ Calculated as mEq of $[(\mathrm{Na}+\mathrm{K})-(\mathrm{Cl}+\mathrm{S})] / 100 \mathrm{~g}$ of DM $(\mathrm{NRC}, 2001)$. 
ings. Samples were composited and stored at $4^{\circ} \mathrm{C}$ with a preservative (Bronopol tablet; D \& F Control Systems Inc., San Ramon, CA) until analyzed (Dairy One Cooperative Inc., Ithaca, NY). Samples were analyzed within $24 \mathrm{~h}$ for fat, true protein, lactose, TS, and MUN using mid-infrared analysis (AOAC International, 2000; method 972.160), and SCC by an optical fluorescent method (AOAC International, 2000; method 978.26). Body condition scores (1 to 5 scale; Wildman et al., 1982) were assessed weekly by 2 individuals and BW was measured weekly from the preliminary period throughout the entire treatment period.

\section{Plasma Sampling and Analyses}

Blood samples were obtained from each cow via coccygeal blood vessel puncture $1 \mathrm{~d}$ before assignment to treatment and 3 times per week from $21 \mathrm{~d}$ prepartum through 56 d postpartum. Plasma was collected following centrifugation $\left(2,800 \times g\right.$ for $15 \mathrm{~min}$ at $\left.4^{\circ} \mathrm{C}\right)$, snapfrozen in liquid $\mathrm{N}_{2}$, and stored at $-20^{\circ} \mathrm{C}$ until analysis. Plasma samples collected from the start of the study through $21 \mathrm{~d}$ postpartum were analyzed for plasma metabolites (glucose, NEFA, BHBA, and insulin). Plasma concentration of glucose was determined by enzymatic analysis (glucose oxidase) using a commercial kit (kit 510-A; Sigma Chemical, St. Louis, MO). Plasma concentration of NEFA was also analyzed by enzymatic analysis (NEFA-C; Wako Pure Chemical Industries Ltd., Osaka, Japan). Plasma concentration of BHBA was determined by enzymatic analysis (BHBA dehydrogenase; kit no. 310; Sigma Chemical). Plasma concentration of insulin was determined by double-antibody RIA (Porcine Insulin RIA, catalog no. PI-12K; Linco Research, Millipore Corp., St. Charles, MO), with a reported specificity to bovine insulin of $90 \%$. Intraassay and interassay coefficients of variation for the insulin RIA were 11.1 and $15.3 \%$, respectively. Plasma samples collected from 1 wk postpartum through 8 wk postpartum also were analyzed for the concentration of haptoglobin (Hp). Plasma concentration of $\mathrm{Hp}$ was measured by enzymatic analysis (Phase Range Haptoglobin Assay; Tridelta Diagnostics Ltd., Morris Plains, NJ). All spectrophotometric measurements were conducted using a VersaMax tunable microplate reader (Molecular Devices LLC, Sunnyvale, CA). Plasma samples collected from calving through $56 \mathrm{~d}$ postpartum were analyzed for progesterone by RIA (Staigmiller et al., 1979; Nara and First, 1981). Intraassay and interassay coefficients of variation for the progesterone RIA were 11.2 and $13.2 \%$, respectively. Ovulation was assumed to have occurred $3 \mathrm{~d}$ before concentrations of plasma progesterone in 2 consecutive samples were $\geq 1 \mathrm{ng} / \mathrm{mL}$ (Smith et al., 2009).

\section{Blood Neutrophil Glycogen}

Blood samples were obtained from each cow via coccygeal blood vessel puncture at $7 \mathrm{~d}$ postcalving and on one day between 40 and $60 \mathrm{~d}$ (average $48 \mathrm{~d} \pm 0.44 \mathrm{SE}$ ) postcalving. Blood PMNL were isolated as previously described (Flaminio et al., 2002) and frozen for subsequent determination of glycogen content. Glycogen content of neutrophils was determined as described previously (Galvão et al., 2010). Briefly, glycogen was hydrolyzed to glucose using amyloglucosidase; available glucose was determined by reacting $50 \mu \mathrm{L}$ of supernatant with a $1-\mathrm{mL}$ mixture of $1 \mathrm{~m} M$ ATP, $0.9 \mathrm{~m} M$ NADP, $5 \mu \mathrm{g}$ of glucose-6-phosphate dehydrogenase, 0.3 $M$ triethanolamine, and $4 \mathrm{mM} \mathrm{MgSO}$. The appearance of NADPH was recorded after the addition of $5 \mu \mathrm{L}$ of hexokinase $(2 \mathrm{mg} / \mathrm{mL})$ as change in optical density at $340 \mathrm{~nm}$ on a spectrophotometer (VersaMax tunable microplate reader; Molecular Devices LLC). This change in optical density was compared with a standard curve of glycogen assayed in a similar fashion, and results were expressed as micrograms of glycogen per $10^{6}$ PMNL.

\section{Endometrial Cytology}

Evaluation of endometrial cytology by low-volume lavage (Gilbert et al., 2005) was determined on all cows at $7 \mathrm{~d}$ postcalving (first lavage) and on one day between 40 and $60 \mathrm{~d}$ (second lavage) postcalving as previously described (Cheong et al., 2011); the perineum of the cow was cleansed and a 64-cm Flex Tip sterile plastic infusion pipette (Exodus Breeders Corp., York, PA) was manipulated through the cervix into the uterus. Sterile saline solution $(20 \mathrm{~mL})$ was injected into the uterus and agitated gently per rectum; then a sample of the fluid was aspirated. The recovered fluid was centrifuged at 58 $\times g$ for $3 \mathrm{~min}$ at room temperature directly onto a glass slide using a cytocentrifuge. After drying, the slides were fixed and stained using a rapid Romanowsky-type staining procedure and examined under $400 \times$ magnification. Two hundred cells were counted from each slide, and the results were expressed as a percentage of PMNL in total cells (excluding erythrocytes). All the slides were read blinded to treatment by the same investigator (T. Yasui). The percentage of PMNL was analyzed subsequently as a continuous variable for both the first and second lavage. Incidence of $\mathrm{CE}$ diagnosed with cut-off point of 10\% PMNL (Cheong et al., 2011) in second lavage was analyzed subsequently as a dichotomous variable. 


\section{Statistical Analyses}

The number of cows enrolled in each treatment was 31 and 30 for control and Cr-Pro, respectively. However, 4 cows were removed from the postpartum or specific DIM data set due to health problems: 1 cow from control after parturition because of retained placenta, ketosis, and displaced abomasum; 1 cow from Cr-Pro after 28 DIM because of mastitis and injury of a teat; 1 cow from the control group after 28 DIM because of mastitis and injury of a teat; and 1 cow from Cr-Pro after 40 DIM because of bloated rumen and mastitis.

Data for DMI and milk yield were reduced to weekly means before analysis. Baseline values collected during the pretreatment week before assignment to treatment were used as covariates for DMI, BW, BCS, and plasma metabolites. Previous 305-d mature-equivalent milk yields were used as covariates for milk yield and milk composition. Weekly (DMI, BW, BCS, milk yield, and milk composition) and 3-times-per-week (plasma metabolites) variables were analyzed using PROC MIXED SAS (version 9.1; SAS Institute Inc., Cary, NC) for a completely randomized design with repeated measures. For plasma metabolites, data were analyzed separately by prepartum and postpartum periods. Model terms were the fixed effects of covariate, treatment, week or day, and the interaction of treatment and week or day. The random effect was cow nested within treatment. For each weekly or 3-times-per-week variable, the cow was subjected to 4 covariance structures (firstorder autoregressive, heterogeneous first-order autoregressive, compound symmetry, and heterogeneous compound symmetry) and the structure yielding the smallest Akaike information criterion was selected. The Kenward-Rogers method was used for calculating denominator degrees of freedom. Covariates were retained in the model if $P<0.10$.

The percentage of PMNL in the total cells in lowvolume lavage was analyzed as a continuous variable for both the first and second lavage using PROC GLM of SAS (version 9.1). Incidence of CE was dichotomously analyzed for second lavage using PROC FREQ of SAS (version 9.1). Kaplan-Meier survival analysis (Kaplan and Meier, 1958) was conducted to evaluate days from calving to first ovulation within 56 DIM. Statistical significance was declared at $P<0.05$ and trends were discussed at $0.05<P \leq 0.15$. Least squares means and standard errors of the mean are reported throughout.

\section{RESULTS}

The effects of Cr-Pro supplementation during the prepartum period and early lactation on performance are described in Table 2. Supplementation with Cr-Pro tended to increase absolute DMI during the prepartum period ( 16.5 vs. $15.8 \mathrm{~kg} / \mathrm{d} ; P=0.07$ ); however, prepartum DMI expressed as a percentage of BW was not affected by treatment (2.30 vs. $2.22 \% ; P=0.25)$. Despite the modest effect on absolute DMI during the prepartum period, postpartum DMI $(\mathrm{kg} / \mathrm{d})$ was not affected by treatment $(P=0.98)$ and postpartum DMI expressed as a percentage of BW actually tended to be slightly lower in cows fed Cr-Pro (3.63 vs. $3.76 \% ; P=$ 0.14 ). Milk yield averaged $42.2 \mathrm{~kg} / \mathrm{d}$ during the 9 -wk postpartum period and was not affected by treatment $(P=0.74)$. Chromium supplementation did not affect the percentage and yield of milk fat $(P=0.46$ and $0.57)$, true protein $(P=0.37$ and 0.36$)$, lactose $(P=$ 0.91 and 0.74$)$, TS $(P=0.46$ and 0.57$), 3.5 \% \mathrm{FCM}(P$ $=0.59)$, or ECM $(P=0.58)$. Cows fed Cr-Pro tended to have slightly higher concentrations of MUN (11.2 vs. $10.6 \mathrm{mg} / \mathrm{dL} ; P=0.08)$ and linear SCC (2.6 vs. $2.0 ; P=$ 0.12 ). Body weight tended to be greater in cows fed CrPro during the prepartum (731 vs. $710 \mathrm{~kg} ; P=0.12$ ) and postpartum (630 vs. $610 \mathrm{~kg} ; P=0.14$ ) periods; however, prepartum and postpartum BCS were not affected by treatment $(P=0.59$ and 0.97$)$.

Results for plasma metabolites, insulin, and Hp along with concentrations of glycogen in blood neutrophils are provided in Table 3. Cows fed Cr-Pro tended to have lower concentrations of plasma NEFA during the prepartum period (184 vs. $211 \mu \mathrm{Eq} / \mathrm{L} ; P=0.08$ ); however, differences during the postpartum period were not significant. Plasma concentrations of BHBA were not affected by treatment during either the prepartum $(P$ $=0.38)$ or postpartum $(P=0.22)$ period. Supplementation with Cr-Pro did not affect overall concentrations of glucose in plasma during either period studied (prepartum $P=0.57$ and postpartum $P=0.46$ ); however, a trend for a treatment by time interaction existed for glucose concentrations during the postpartum period, such that concentrations were lower in cows fed Cr-Pro on d 1 postpartum, but similar for the rest of the study period $(P=0.002$; Figure 1). Plasma concentrations of insulin were not affected by treatment during either the prepartum $(P=0.23)$ or postpartum $(P=0.52)$ period. Plasma concentrations of $\mathrm{Hp}$, analyzed either from weekly postpartum samples $(P=0.90)$ or during only the first week postpartum $(P=0.94)$, were not affected by treatment. Glycogen content of neutrophils harvested from whole blood on d 7 postpartum and one day between d 40 and 60 postpartum was not affected by treatment $(P=0.46$ and 0.77$)$. Days to first ovulation was not affected by treatment $(P=0.64$; data not shown).

Results for endometrial cytology conducted on d 7 postpartum (first lavage) and one day during d 40 to 60 postpartum (second lavage) are presented in Table 
Table 2. Least squares means for DMI, milk yield, milk composition, and BW and BCS for cows fed the control diet or chromium propionate (Cr-Pro) during the periparturient period and early lactation

\begin{tabular}{|c|c|c|c|c|c|c|}
\hline \multirow[b]{2}{*}{ Item } & \multicolumn{2}{|c|}{ Treatment } & \multirow[b]{2}{*}{ SEM } & \multicolumn{3}{|c|}{$P$-value ${ }^{1}$} \\
\hline & Control & Cr-Pro & & Trt & Wk & Trt $\times W k$ \\
\hline \multicolumn{7}{|l|}{ DMI } \\
\hline Prepartum, kg/d & 15.8 & 16.5 & 0.3 & 0.07 & $<0.001$ & 0.26 \\
\hline Prepartum, \% of BW & 2.22 & 2.30 & 0.05 & 0.25 & $<0.001$ & 0.49 \\
\hline Postpartum, kg/d & 22.9 & 22.9 & 0.3 & 0.98 & $<0.001$ & 0.33 \\
\hline Postpartum, \% of BW & 3.76 & 3.63 & 0.06 & 0.14 & $<0.001$ & 0.14 \\
\hline Milk, ${ }^{2} \mathrm{~kg} / \mathrm{d}$ & 42.0 & 42.5 & 0.9 & 0.74 & $<0.001$ & 0.97 \\
\hline Fat, $\%$ & 3.73 & 3.80 & 0.07 & 0.46 & $<0.001$ & 0.94 \\
\hline Fat, kg/d & 1.53 & 1.56 & 0.04 & 0.57 & $<0.001$ & 0.85 \\
\hline True protein, \% & 3.01 & 3.07 & 0.05 & 0.37 & $<0.001$ & 0.17 \\
\hline True protein, $\mathrm{kg} / \mathrm{d}$ & 1.24 & 1.26 & 0.02 & 0.36 & 0.60 & 0.84 \\
\hline Lactose, \% & 4.81 & 4.80 & 0.02 & 0.91 & $<0.001$ & 0.26 \\
\hline Lactose, $\mathrm{kg} / \mathrm{d}$ & 2.02 & 2.05 & 0.05 & 0.74 & $<0.001$ & 0.49 \\
\hline $\mathrm{SCC}\left(\mathrm{LS}^{3}\right)$ & 2.0 & 2.6 & 0.3 & 0.12 & $<0.001$ & 0.14 \\
\hline Urea $\mathrm{N}, \mathrm{mg} / \mathrm{dL}$ & 10.6 & 11.2 & 0.2 & 0.08 & 0.07 & 0.52 \\
\hline $\mathrm{TS}, \%$ & 12.5 & 12.6 & 0.1 & 0.40 & $<0.001$ & 0.99 \\
\hline $\mathrm{TS}, \mathrm{kg} / \mathrm{d}$ & 5.19 & 5.27 & 0.11 & 0.62 & $<0.001$ & 0.98 \\
\hline $3.5 \% \mathrm{FCM}^{4}{ }^{4} \mathrm{~kg} / \mathrm{d}$ & 43.0 & 43.7 & 0.9 & 0.59 & $<0.001$ & 0.63 \\
\hline $\mathrm{ECM},{ }^{5} \mathrm{~kg} / \mathrm{d}$ & 42.0 & 42.7 & 0.9 & 0.58 & $<0.001$ & 0.92 \\
\hline \multicolumn{7}{|l|}{$\mathrm{BW}, \mathrm{kg}$} \\
\hline Prepartum & 710 & 731 & 9 & 0.12 & 0.002 & 0.19 \\
\hline Postpartum & 610 & 630 & 10 & 0.14 & $<0.001$ & 0.18 \\
\hline \multicolumn{7}{|l|}{$\mathrm{BCS}$} \\
\hline Prepartum & 3.35 & 3.40 & 0.06 & 0.59 & 0.45 & 0.97 \\
\hline Postpartum & 2.89 & 2.89 & 0.05 & 0.97 & $<0.001$ & 0.14 \\
\hline \multicolumn{7}{|c|}{${ }^{1}$ Trt $=$ treatment; $\mathrm{Wk}=$ week } \\
\hline $\begin{array}{l}{ }^{2} \text { Represents milk yields } \\
\text { week postpartum. } \\
{ }^{3} \mathrm{LS}=\text { linear score }=[-3 \\
{ }^{4} \mathrm{FCM}=(0.4324 \times \mathrm{kg} \text { of } \\
{ }^{5} \mathrm{ECM}=(0.323 \times \mathrm{kg} \text { of }\end{array}$ & $\begin{array}{l}\text { daily fron } \\
+(3.3219 \\
-(16.216> \\
(12.82 \times)\end{array}$ & $\begin{array}{l}\text { arturition } \\
\times \ln (\mathrm{SCC}\end{array}$ & $\begin{array}{l}\text { ough } 63 \\
00) / 2.3\end{array}$ & stpartı & ad then a & aged for eac \\
\hline
\end{tabular}

4. Six cows from the control group were not used for analysis for first lavage ( 1 due to aforementioned removal from the data set due to a health problem, 1 due to difficulty to retrieve lavage, and 4 due to difficulty to distinguish PMNL from other cells). Two cows from the Cr-Pro-treated group were not used for analysis for first lavage due to difficulty to distinguish PMNL from other cells. Four cows from the control group (2 cows due to aforementioned removal from the data set and 2 cows due to difficulty to retrieve lavage) were not used to analyze for second lavage. Two cows from the Cr-Pro-treated group were not used for analysis for second lavage due to aforementioned removal from the data set. Cows fed Cr-Pro tended to have increased neutrophil infiltration of the uterus at $7 \mathrm{~d}$ postpartum (41.1 vs. $32.8 \%$ of cells; $P=0.15$ ); however, the percentage of PMNL was not affected by treatment at 40 to 60 postpartum $(P=0.41)$. Cows fed Cr-Pro had decreased incidence of $\mathrm{CE}$ as assessed using data from the second lavage ( 8 out of 28 cows with $\mathrm{CE}$ for cows fed Cr-Pro vs. 16 out of 27 cows with CE for controls; $P=0.02)$.

\section{DISCUSSION}

In this experiment, cows fed Cr-Pro tended to have higher absolute DMI during the prepartum period; however, DMI expressed as a percentage of BW was similar between treatments. These results generally reflect the literature, in that Hayirli et al. (2001) reported that $\mathrm{Cr}$ supplementation increased prepartum DMI and McNamara and Valdez (2005) described a nonsignificant increase in prepartum DMI, but others have reported no effect of $\mathrm{Cr}$ supplementation on prepartum DMI (Yang et al., 1996; Smith et al., 2005; Sadri et al., 2009). Although several studies show that DMI during the postpartum period was increased with $\mathrm{Cr}$ supplementation (Hayirli et al., 2001; McNamara and Valdez, 2005; Smith et al., 2005; Sadri et al., 2009; Soltan, 2010), postpartum DMI was not affected by treatment in the current study or in the study of Yang et al. (1996). It is not known whether effects of $\mathrm{Cr}$ on DMI are direct, indirect mediated through other mechanisms in metabolism, or in the case of postpartum DMI, simply a result of generally increased milk yield with $\mathrm{Cr}$ 


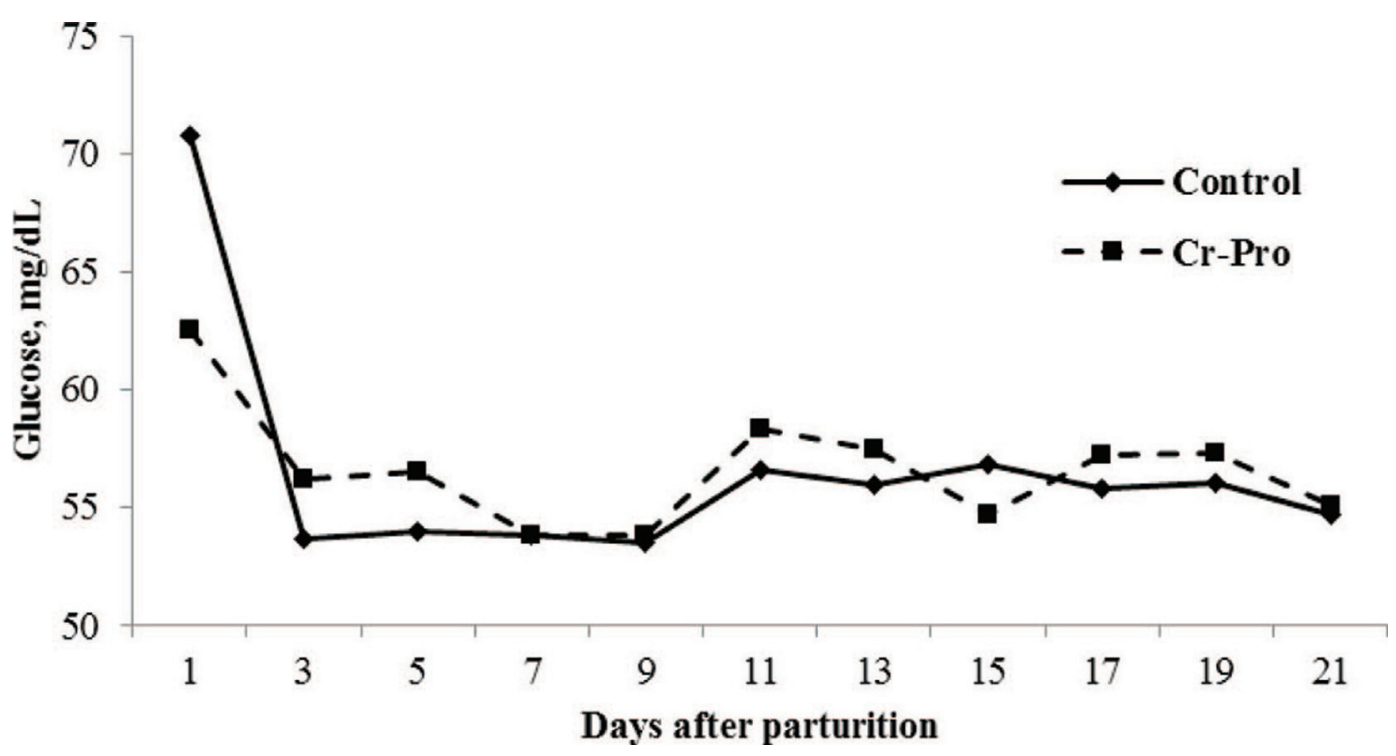

Figure 1. Postpartum plasma glucose concentration in cows fed the control diet or chromium propionate (Cr-Pro) during the periparturient period and early lactation. Values are LSM; SEM averaged $1.84 \mathrm{mg} / \mathrm{dL}$; the $P$-value for the interaction of treatment $\times$ day was 0.06 . At $1 \mathrm{~d}$ after parturition, plasma glucose concentration was lower in cows fed Cr-Pro than the control $(P=0.002)$.

supplementation as described below. Allen et al. (2009) proposed that oxidative fuel supply and subsequent generation of ATP in excess of liver requirements can decrease DMI. Nonesterified FA are one of the major fuel sources for the liver during the periparturient period, and several studies (Hayirli et al., 2001; Smith et al., 2005; Soltan, 2010) have reported both increased DMI and decreased NEFA in cows fed Cr. It cannot

Table 3. Plasma NEFA, BHBA, glucose, insulin, and haptoglobin (Hp), and blood PMNL glycogen concentrations in cows fed the control diet or chromium propionate (Cr-Pro) during the periparturient period and early lactation

\begin{tabular}{|c|c|c|c|c|c|c|}
\hline \multirow[b]{2}{*}{ Item } & \multicolumn{2}{|c|}{ Treatment } & \multirow[b]{2}{*}{ SEM } & \multicolumn{3}{|c|}{$P$-value ${ }^{1}$} \\
\hline & Control & Cr-Pro & & Trt & Wk & Trt $\times W k$ \\
\hline \multicolumn{7}{|l|}{$\mathrm{NEFA}, \mu \mathrm{Eq} / \mathrm{L}$} \\
\hline Prepartum period $^{2}$ & 210.7 & 183.8 & 10.5 & 0.08 & $<0.01$ & 0.78 \\
\hline Postpartum period $^{3}$ & 684.3 & 705.7 & 45.0 & 0.74 & $<0.01$ & 0.49 \\
\hline \multicolumn{7}{|l|}{ BHBA, mg/dL } \\
\hline Prepartum period $^{2}$ & 4.23 & 4.41 & 0.15 & 0.38 & 0.49 & 0.27 \\
\hline Postpartum period $^{3}$ & 6.64 & 7.73 & 0.62 & 0.22 & 0.02 & 0.17 \\
\hline \multicolumn{7}{|l|}{ Glucose, $\mathrm{mg} / \mathrm{dL}$} \\
\hline Prepartum period $^{2}$ & 63.43 & 63.77 & 0.68 & 0.73 & 0.47 & 0.99 \\
\hline Postpartum period ${ }^{3}$ & 56.51 & 56.63 & 0.78 & 0.91 & $<0.01$ & 0.05 \\
\hline \multicolumn{7}{|l|}{ Insulin, $\mathrm{ng} / \mathrm{mL}$} \\
\hline Prepartum period $^{2}$ & 0.59 & 0.63 & 0.02 & 0.23 & $<0.01$ & 0.75 \\
\hline Postpartum period $^{3}$ & 0.26 & 0.24 & 0.02 & 0.52 & $<0.01$ & 0.39 \\
\hline \multicolumn{7}{|l|}{$\mathrm{Hp}, \mathrm{mg} / \mathrm{mL}$} \\
\hline Postpartum period ${ }^{4}$ & 0.69 & 0.70 & 0.05 & 0.90 & $<0.01$ & 0.37 \\
\hline 1 wk postpartum ${ }^{5}$ & 0.97 & 0.96 & 0.10 & 0.94 & - & - \\
\hline \multicolumn{7}{|l|}{ Glycogen, $\mu \mathrm{g} / 10^{6} \mathrm{PMNL}$} \\
\hline $7 \mathrm{~d}$ postpartum ${ }^{6}$ & 2.64 & 3.08 & 0.44 & 0.46 & - & - \\
\hline 40-60 d postpartum 7 & 4.64 & 4.81 & 0.44 & 0.77 & - & - \\
\hline
\end{tabular}

${ }^{1}$ Trt $=$ treatment; $\mathrm{Wk}=$ week.

${ }^{2}$ Represents plasma samples collected 3 times per week from 3 wk prepartum through 1 wk prepartum.

${ }^{3}$ Represents plasma samples collected 3 times per week from 1 wk postpartum through 8 wk postpartum.

${ }^{4}$ Represents plasma samples collected weekly from 1 wk postpartum through 8 wk postpartum.

${ }^{5}$ Represents plasma samples collected from 1 wk postpartum only.

${ }^{6}$ Represents PMNL samples isolated at 7 d postpartum.

${ }^{7}$ Represents PMNL samples isolated on one day between 40 and $60 \mathrm{~d}$ postpartum. 
Table 4. Percentage of neutrophils in first uterine lavage and incidence of cytological endometritis (CE) in second uterine lavage from cows fed the control diet or chromium propionate (Cr-Pro) during the periparturient period and early lactation

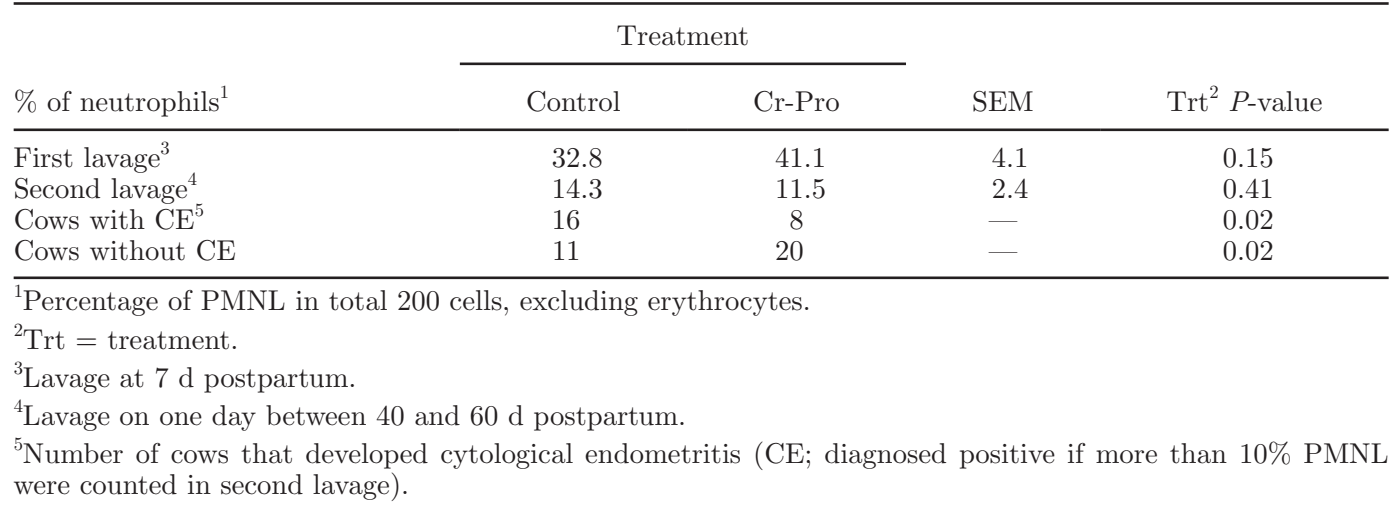

be determined whether the decreased NEFA results in increased DMI or vice versa; however, McNamara and Valdez (2005) suggested that Cr-Pro supplementation may reduce net lipolysis, which would support a role for decreased NEFA leading to increased DMI. In addition, feeding organic $\mathrm{Cr}$ markedly decreased serum cortisol in stressed calves (Mowat et al., 1993). Therefore, an alternative explanation is that feeding $\mathrm{Cr}$ may lead to an increase in feed intake by mitigating stress responses in dairy cows. Regardless, the effect of Cr-Pro on DMI in the current study were modest and confined to the prepartum period

Supplemental Cr in dairy cows during the periparturient period has frequently increased milk yield of cows during early lactation (Hayirli et al., 2001; McNamara and Valdez, 2005; Smith et al., 2005; Sadri et al., 2009; Soltan, 2010); however, milk yield was not increased in the current study and not in the multiparous cows in Yang et al. (1996). The overall effect of treatment on the percentage and yield of major milk components (e.g., fat, true protein, lactose, and TS) was not significant. Tendencies existed for increased concentrations of MUN and increased linear SCC in cows fed Cr-Pro. In general, the literature suggests minimal effects of $\mathrm{Cr}$ supplementation on milk composition. Sadri et al. (2009) reported that $\mathrm{Cr}$ supplementation decreased milk protein content and McNamara and Valdez (2005) indicated that cows fed Cr-Pro had decreased concentrations of milk fat. However, other investigators reported no effect of $\mathrm{Cr}$ supplementation on milk component percentages (Hayirli et al., 2001; Smith et al., 2005; Soltan, 2010). Body weight tended to be increased in cows fed $\mathrm{Cr}$ during the prepartum and postpartum periods, although differences were small. Smith et al. (2005) reported that administering increasing amounts of $\mathrm{Cr}$ linearly increased postpartum BW; however, the effect of $\mathrm{Cr}$ on prepartum BW was not significant. Oth- ers have reported that feeding $\mathrm{Cr}$ did not affect BW (Hayirli et al., 2001; McNamara and Valdez, 2005; Sadri et al., 2009). Furthermore, no effect of treatment on BCS was detected in the current study. McNamara and Valdez (2005) also reported a lack of effect of Cr-Pro on BCS, but another study showed that prepartum BCS significantly increased with increasing $\mathrm{Cr}$ supplementation (Smith et al., 2005). Effects of $\mathrm{Cr}$ on predicted energy balance during the prepartum period were not significant (Smith et al., 2005).

Consistent with other studies (Hayirli et al., 2001; Smith et al., 2008; Soltan, 2010), Cr-Pro supplementation during the prepartum period tended to decrease plasma NEFA concentrations in the current experiment. Given that DMI tended to be increased concurrently with the trend for reduced NEFA, decreased NEFA might be as a result of increased energy intake. Hayirli et al. (2001) reported that increased serum insulin concentrations were associated with decreased plasma NEFA concentrations in cows supplemented with $\mathrm{Cr}$; however, insulin concentrations were not affected by treatment in our experiment. As described above, McNamara and Valdez (2005) reported that CrPro supplementation reduced net lipolysis and that $\mathrm{Cr}$ might have specific actions on adipose tissue metabolism that would be consistent with increased responses of adipose tissue to circulating insulin.

Although NEFA tended to be decreased during the prepartum period by Cr-Pro supplementation, effects of $\mathrm{Cr}$ on postpartum NEFA and BHBA were not significant. Smith et al. (2005) also reported that $\mathrm{Cr}$ supplementation did not affect postpartum NEFA and BHBA; however, others have reported that Cr supplementation decreased both NEFA and BHBA (Yang et al., 1996), NEFA only (Hayirli et al., 2001; Bryan et al., 2004), and BHBA only (Besong, 1996; Sadri et al., 2012). 
Although overall effects of Cr-Pro on plasma glucose concentration were not significant during either the prepartum or postpartum periods, plasma glucose concentration of Cr-Pro-fed animals was lower than that of controls at 1 wk postpartum. Besong (1996) showed that the plasma glucose level decreased after parturition, regardless of feeding $\mathrm{Cr}$; however, to this point, no study has shown that supplemental $\mathrm{Cr}$ reduced plasma glucose concentration right after parturition. Postpartum plasma glucose concentrations were decreased linearly $(P=0.19)$ by administering increasing amounts of $\mathrm{Cr}$ (Smith et al., 2008), whereas milk yield was increased by supplemental $\mathrm{Cr}$ in the same experiment (Smith et al., 2005). Therefore, supplemental Cr-Pro might increase glucose uptake by the mammary gland or increase uptake of glucose by other tissues, resulting in low blood glucose concentration.

Several studies have shown that $\mathrm{Cr}$ has immunomodulatory effects in dairy cows (Burton et al., 1993; Burton et al., 1996; Chang et al., 1996). However, no studies, to date, have evaluated the effect of $\mathrm{Cr}$ on acute-phase proteins, which increase in concentration following stimulating conditions such as infection, inflammation, or trauma (Eckersall, 2000). Haptoglobin typically has low circulating concentrations, but increases over 100-fold on stimulation (Eckersall, 2000). Furthermore, increased circulating Hp concentrations during wk-1 postcalving have been associated with uterine disease in dairy cows (Huzzey et al., 2009; Chan et al., 2010; Dubuc et al., 2010). Burton et al. (1996) reported that dairy cows fed $\mathrm{Cr}$ had decreased in vitro concentrations of IFN- $\gamma$, IL-2, and TNF- $\alpha$ following mitogen stimulation of mononuclear cells collected during the peripartum period. Among the proinflammatory cytokines, TNF- $\alpha$ stimulates hepatic production of acute-phase proteins (Eckersall, 2000). Therefore, it was expected that feeding Cr-Pro might result in lower Hp concentrations through an immunomodulatory effect. However, concentration of Hp was not affected by feeding Cr-Pro. The lack of response of plasma Hp to Cr-Pro supplementation suggests similar inflammatory states between cows fed the 2 treatments.

The PMNL found in peripheral blood accumulate glycogen intracellularly for use as reserve energy to meet requirements for their activity, especially phagocytosis (Naidu and Newbould, 1973; Weisdorf et al., 1982). Galvão et al. (2010) suggested that low glucose levels observed during the transition to lactation could lead to decreased PMNL glycogen stores, thereby impairing phagocytic and killing capabilities. Also, impaired PMNL function in diabetic rats was abolished with insulin treatment, even with no marked change in glycemia, which indicates that insulin may have a direct effect on neutrophil metabolism and function (Alba-Loureiro et al., 2006). Therefore, our hypothesis was that feeding Cr-Pro would increase the glycogen level in neutrophils by enhancing insulin function. The results showed that glycogen content of PMNL was not affected by Cr-Pro supplementation at either $\mathrm{d} 7$ postpartum or when sampled on $1 \mathrm{~d}$ between $\mathrm{d} 40$ and 60 postpartum. Overall, the results are consistent with the lack of response of most other variables related to glucose metabolism in this experiment.

In this experiment, cows fed Cr-Pro tended to have an increased percentage of neutrophils in the uterine lavage at $7 \mathrm{~d}$ postpartum and incidence of $\mathrm{CE}$, characterized between 40 and $60 \mathrm{~d}$ postpartum, was decreased by about $50 \%$. Gilbert et al. (2007) reported that cows with the greatest influx of PMNL to the uterus on the day of calving had the lowest rate of positive bacterial culture and prevalence of $\mathrm{CE}$ later in lactation. Therefore, early infiltration of PMNL into the uterus postcalving may be an important factor in reducing subsequent CE; cows fed Cr-Pro in this experiment fit this response pattern quite well.

Because CE has been associated with decreased subsequent reproductive performance (Gilbert et al., 2005) and our results suggest that cows fed Cr-Pro have lower incidence of $\mathrm{CE}$, we hypothesize that feeding Cr-Pro would improve reproductive performance. Limited published results suggest that effects of $\mathrm{Cr}$ supplementation on reproductive performance have been inconsistent. In intensively grazed dairy cows, $\mathrm{Cr}$ supplementation tended to increase the percentage of cows pregnant in the first $28 \mathrm{~d}$ of the mating season (Bryan et al., 2004) and Soltan (2010) reported that that a lower proportion of noncycling cows was observed in cows fed Cr along with a higher 28-d pregnancy rate compared with controls. However, Yang et al. (1996) determined that the effect of $\mathrm{Cr}$ supplementation on days to first estrus and days open was not significant. Future research should continue to evaluate whether Cr-Pro supplementation during the periparturient period and early lactation improves reproduction in dairy cattle.

\section{CONCLUSIONS}

Supplementation of cows with Cr-Pro during the periparturient period and early lactation in this study resulted in trends for modestly higher DMI and lower NEFA during the prepartum period, but no effects on postpartum DMI, milk yield, or milk composition. Furthermore, effects of Cr-Pro on postpartum energy metabolism and inflammation were not significant. However, cows fed Cr-Pro during the periparturient period and early lactation had decreased incidence of $\mathrm{CE}$ 
during early lactation, which suggests the opportunity for further evaluation of the potential effect of Cr-Pro on reproductive performance.

\section{ACKNOWLEDGMENTS}

The authors sincerely appreciate the assistance of the following individuals in completing the study at Cornell University (Ithaca, NY): J. Felippe, R. Butler, S. Pelton, K. Donnan, E. Diehl, A. Jones, Y. Bing, E. Martens, B. Pomeroy, C. Wall, C. Butler, L. Stephens, J. Huzzey, K. Schoenberg, and R. Higgs, and the staff at the Cornell University Dairy Teaching and Research Center and K. Galvão and L. Neumann at the University of Florida (Gainesville). This study was funded in part by Kemin Industries Inc. (Des Moines, IA).

\section{REFERENCES}

Alba-Loureiro, T. C., S. M. Hirabara, J. R. Mendonça, R. Curi, and T. C. Pithon-Curi. 2006. Diabetes causes marked changes in function and metabolism of rat neutrophils. J. Endocrinol. 188:295-303.

Allen, M. S., B. J. Bradford, and M. Oba. 2009. The hepatic oxidation theory of the control of feed intake and its application to ruminants. J. Anim. Sci. 87:3317-3334.

AOAC International. 2000. Official Methods of Analysis. 17th ed. AOAC International, Arlington, VA.

AOAC International. 2006. Official Methods of Analysis. 18th ed. International, Gaithersburg, MD.

Besong, S. A. 1996. Influence of supplemental chromium picolinate on the concentrations of hepatic triglyceride and blood metabolites in dairy cattle. PhD Diss. University of Kentucky, Lexington.

Bryan, M. A., M. T. Socha, and D. J. Tomlinson. 2004. Supplementing intensively grazed late-gestation and early-lactation dairy cattle with chromium. J. Dairy Sci. 87:4269-4277.

Burton, J. L., B. A. Mallard, and D. N. Mowat. 1993. Effects of supplemental chromium on immune responses of periparturient and early lactation dairy cows. J. Anim. Sci. 71:1532-1539.

Burton, J. L., B. J. Nonnecke, P. L. Dubeski, T. H. Elsasser, and B. A. Mallard. 1996. Effects of supplemental chromium on production of cytokines by mitogen-stimulated bovine peripheral blood mononuclear cells. J. Dairy Sci. 79:2237-2246.

Butler, S. T., S. H. Pelton, and W. R. Butler. 2006. Energy balance, metabolic status, and the first postpartum ovarian follicle wave in cows administered propylene glycol. J. Dairy Sci. 89:2938-2951.

Chan, J. P.-W., C.-C. Chang, W.-L. Hsu, W.-B. Liu, and T.-H. Chen. 2010. Association of increased serum acute-phase protein concentrations with reproductive performance in dairy cows with postpartum metritis. Vet. Clin. Pathol. 39:72-78.

Chang, X., B. A. Mallard, and D. N. Mowat. 1996. Effects of chromium on health status, blood neutrophil phagocytosis and in vitro lymphocyte blastogenesis of dairy cows. Vet. Immunol. Immunopathol. 52:37-52.

Cheong, S. H., D. V. Nydam, K. N. Galvão, B. M. Crosier, and R. O. Gilbert. 2011. Cow-level and herd-level risk factors for subclinical endometritis in lactating Holstein cows. J. Dairy Sci. 94:762-770.

DuBois, M., K. A. Gilles, J. K. Hamilton, P. A. Rebers, and F. Smith. 1956. Colorimetric method for determination of sugars and related substances. Anal. Chem. 28:350-356.

Dubuc, J., T. F. Duffield, K. E. Leslie, J. S. Walton, and S. J. LeBlanc. 2010. Risk factors for postpartum uterine diseases in dairy cows. J. Dairy Sci. 93:5764-5771.

Eckersall, P. D. 2000. Recent advances and future prospects for the use of acute phase proteins as markers of disease in animals. Rev. Med. Vet. 151:577-584.
Faldyna, M., A. Pechova, and J. Krejci. 2003. Chromium supplementation enhances antibody response to vaccination with tetanus toxoid in cattle. J. Vet. Med. B Infect. Dis. Vet. Public Health $50: 326-331$

Flaminio, M. J. B. F., B. R. Rush, E. G. Davis, K. Hennessy, W. Shuman, and M. J. Wilkerson. 2002. Simultaneous flow cytometric analysis of phagocytosis and oxidative burst activity in equine leukocytes. Vet. Res. Commun. 26:85-92.

Galvão, K. N., M. J. B. F. Flaminio, S. B. Brittin, R. Sper, M. Fraga, L. Caixeta, A. Ricci, C. L. Guard, W. R. Butler, and R. O. Gilbert. 2010. Association between uterine disease and indicators of neutrophil and systemic energy status in lactating Holstein cows. J. Dairy Sci. 93:2926-2937.

Gilbert, R., N. Santos, K. Galvão, S. Brittin, and H. Roman. 2007. The relationship between postpartum uterine bacterial infection (BI) and subclinical endometritis (SE). J. Dairy Sci. 90(Suppl. 1):469. (Abstr.)

Gilbert, R. O., S. T. Shin, C. L. Guard, H. N. Erb, and M. Frajblat. 2005. Prevalence of endometritis and its effects on reproductive performance of dairy cows. Theriogenology 64:1879-1888.

Hall, M. B. 2009. Determination of starch, including maltooligosaccharides, in animal feeds: Comparison of methods and a method recommended for AOAC collaborative study. J. AOAC Int. 92:42-49.

Hayirli, A., D. R. Bremmer, S. J. Bertics, M. T. Socha, and R. R. Grummer. 2001. Effect of chromium supplementation on production and metabolic parameters in periparturient dairy cows. J. Dairy Sci. 84:1218-1230.

Huzzey, J. M., T. F. Duffield, S. J. LeBlanc, D. M. Veira, D. M. Weary, and M. A. G. von Keyserlingk. 2009. Short communication: Haptoglobin as an early indicator of metritis. J. Dairy Sci. 92:621-625.

Kaplan, E. L., and P. Meier. 1958. Nonparametric estimation from incomplete observations. J. Am. Stat. Assoc. 53:457-481.

Krishnamoorthy, U., T. V. Muscato, C. J. Sniffen, and P. J. Van Soest. 1982. Nitrogen fractions in selected feedstuffs. J. Dairy Sci. $65: 217-225$.

McNamara, J. P., and F. Valdez. 2005. Adipose tissue metabolism and production responses to calcium propionate and chromium propionate. J. Dairy Sci. 88:2498-2507.

Mowat, D. N., X. Chang, and W. Z. Yang. 1993. Chelated chromium for stressed feeder calves. Can. J. Anim. Sci. 73:49-55.

Naidu, T. G., and F. H. Newbould. 1973. Glycogen in leukocytes from bovine blood and milk. Can. J. Comp. Med. 37:47-55.

Nara, B. S., and N. L. First. 1981. Effect of indomethacin and prostaglandin $\mathrm{F}_{2 \alpha}$ on parturition in swine. J. Anim. Sci. 52:1360-1370.

NRC. 2001. Nutrient Requirements of Dairy Cattle. 7th rev. ed. National Academy Press, Washington, DC.

Ospina, P. A., D. V. Nydam, T. Stokol, and T. R. Overton. 2010. Associations of elevated nonesterified fatty acids and $\beta$-hydroxybutyrate concentrations with early lactation reproductive performance and milk production in transition dairy cattle in the northeastern United States. J. Dairy Sci. 93:1596-1603.

Pechova, A., and L. Pavlata. 2007. Chromium as an essential nutrient: A review. Vet. Med. (Praha) 52:1-18.

Roche, J. R., N. C. Friggens, J. K. Kay, M. W. Fisher, K. J. Stafford, and D. P. Berry. 2009. Invited review: Body condition score and its association with dairy cow productivity, health, and welfare. J. Dairy Sci. 92:5769-5801.

Sadri, H., G. R. Ghorbani, H. R. Rahmani, A. H. Samie, M. Khorvash, and R. M. Bruckmaier. 2009. Chromium supplementation and substitution of barley grain with corn: Effects on performance and lactation in periparturient dairy cows. J. Dairy Sci. 92:5411-5418.

Sadri, H., H. R. Rahmani, M. Khorvash, G. R. Ghorbani, and R. M. Bruckmaier. 2012. Chromium supplementation and substitution of barley grain with corn: Effects on metabolite and hormonal responses in periparturient dairy cows. J. Anim. Physiol. Anim. Nutr. (Berl.) 96:220-227.

Smith, K. L., W. R. Butler, and T. R. Overton. 2009. Effects of prepartum 2,4-thiazolidinedione on metabolism and performance in transition dairy cows. J. Dairy Sci. 92:3623-3633. 
Smith, K. L., M. R. Waldron, J. K. Drackley, M. T. Socha, and T. R. Overton. 2005. Performance of dairy cows as affected by prepartum dietary carbohydrate source and supplementation with chromium throughout the transition period. J. Dairy Sci. 88:255-263.

Smith, K. L., M. R. Waldron, L. C. Ruzzi, J. K. Drackley, M. T. Socha, and T. R. Overton. 2008. Metabolism of dairy cows as affected by prepartum dietary carbohydrate source and supplementation with chromium throughout the periparturient period. J. Dairy Sci. 91:2011-2020.

Soltan, M. A. 2010. Effect of dietary chromium supplementation on productive and reproductive performance of early lactating dairy cows under heat stress. J. Anim. Physiol. Anim. Nutr. (Berl.) 94:264-272.

Spears, J. W. 2000. Micronutrients and immune function in cattle. Proc. Nutr. Soc. 59:587-594.

Staigmiller, R. B., R. E. Short, R. A. Bellows, and J. B. Carr. 1979 Effect of nutrition on response to exogenous FSH in beef cattle. J. Anim. Sci. 48:1182-1190.

Van Soest, P. J., J. B. Robertson, and B. A. Lewis. 1991. Methods for dietary fiber, neutral detergent fiber, and nonstarch polysaccharides in relation to animal nutrition. J. Dairy Sci. 74:3583-3597.
Vincent, J. B. 2004. Recent advances in the nutritional biochemistry of trivalent chromium. Proc. Nutr. Soc. 63:41-47.

Wathes, D. C., Z. Cheng, W. Chowdhury, M. A. Fenwick, R. Fitzpatrick, D. G. Morris, J. Patton, and J. J. Murphy. 2009. Negative energy balance alters global gene expression and immune responses in the uterus of postpartum dairy cows. Physiol. Genomics $39: 1-13$.

Weisdorf, D. J., P. R. Craddock, and H. S. Jacob. 1982. Granulocytes utilize different energy sources for movement and phagocytosis. Inflammation 6:245-256.

Wildman, E. E., G. M. Jones, P. E. Wagner, R. L. Boman, H. F. Troutt Jr., and T. N. Lesch. 1982. A dairy cow body condition scoring system and its relationship to selected production characteristics. J. Dairy Sci. 65:495-501.

Yang, W. Z., D. N. Mowat, A. Subiyatno, and R. M. Liptrap. 1996. Effects of chromium supplementation on early lactation performance of Holstein cows. Can. J. Anim. Sci. 76:221-230. 